\title{
RUINING, DEMOLITION AND REGENERATION IN URBAN SPACE: SKETCHING THE RESEARCH PROBLEM
}

\author{
Sylwia Kaczmarek \\ Urban Regeneration Laboratory \\ Institute of Urban Geography and Tourism Studies \\ Faculty of Geographical Sciences \\ University of Łódź \\ Kopcińskiego 31, 90-142 Łódź: Poland \\ e-mail: sylwia.kaczmarek@geo.uni.lodz.pl
}

\begin{abstract}
The paper is intended to examine fundamental research problems connected with two processes that currently feature in urban space: demolition and regeneration as well as relationships between them seen from the perspective of diverse conceptual and theoretical approaches debated in geographic urban studies. Regeneration understood as a sequence of planned actions is about the redevelopment of degraded urban areas. Its idea is to introduce spatial, economic, social, and cultural changes in these areas to restore their social attributes, such as: improved standard of living, sustainable positive relations among various user groups, improved comfort in using the areas, and elimination of the existing inequalities. Demolition of a city means destruction of its infrastructure leading to morphological, functional, social, and cultural transformations. Knowledge about the reasons, course and effects of demolition helps us decide what types of demolition best fit given circumstances and subsequently propose effective remedy measures. By identifying relationships between demolition and regeneration in contemporary cities we can learn more about both processes and, consequently, more efficiently modernise organisation of space and its arrangement to meet the needs and requirements of present and future users. In conclusion we propose research questions which delineate the direction of further interdisciplinary studies in this field.
\end{abstract}

\section{Key words}

city $\bullet$ urban studies $\bullet$ demolition $\bullet$ urban regeneration $\bullet$ organisation of space $\bullet$ living conditions $\bullet$ quality of life

\section{Introduction}

Each city can be approached in two ways: as a material, physical structure which performs many functions and changes over time or as a complex social structure which uses space and also changes over time. Relationships among groups of users (residents, newcomers) as well as links between the social and material structure define a city 
as a space that transforms and provides a framework for the exchange of goods (material and immaterial) and services. Transformations are directly triggered by efforts involved in trying to match the material urban sphere with the needs, expectations, and requirements of people who use it. The history of cities clearly suggests that the system of culture with the hierarchy of values recognised by communities at a given stage of their development is one amongst factors that are considered important for how societies shape urban space. Thus, transformation of a city - understood as a territorial functional and spatial but also social structure - is its natural, inherent attribute and a factor, which importantly identifies the distinctiveness and individuality of settlement units. The analysis of transformations of spatial and functional as well as social and cultural structures has been a research problem taken up for years in urban geography, urban planning, and sociological studies.

Transformations of spatial and functional structures in cities and the resultant changes in their communities are effects of a complex network of reasons, circumstances, courses of events and consequences. Striving for a rational shaping of urban space, understood as a space for exchange (of tangible and intangible goods and services), is not always the outcome of a planned sequence of actions stemming from the analysis of evolving user needs and undertaken to meet them. In many instances caused by the war or natural or anthropogenic disasters the organisation and arrangement of urban space need or even must be modernised. Cities as active structures that have been in existence for many centuries either provoke conflicts or become theatres of conflicts, they experience aggression (including terrorist attacks), unrest, extreme natural phenomena and consequences of wrong decisions taken by people. The shaping of cities is a complex process that features continuously in their histories in many sorts of ways: as planned transformations that are put in place evolutionary, radically or even revolutionary as effects of unplanned events (natural or human inflicted disasters, wars and other military actions). In urban areas adjustment of space organisation and equipment to user needs is triggered by many factors. We can mention here: the size of population and their characteristics (age structure, gender composition, education, ethnic and national affiliation, religion), advancement of a given civilisation centre (economic foundations, functions of the city, population and diversity of urban institutions, type of housing, transportation network, availability of technical equipment: water supply, sewage system, etc., how public space is arranged and used), and above all, its location and functional circumstances (physical and geographic characteristics, links with other centres, importance in the settlement network at different reference levels: local, regional, supra-regional, geopolitical context: wars, conquers, local and regional conflicts). Cultural circumstances and settlement traditions of the population living in different urban areas are also important elements of the process. All of these references demonstrate that continuous spatial-functional and social-cultural transformations of cities are vital components of their continuity.

Alongside with the advancements of civilisation, housing, production, service, leisure, and transportation areas transform when it comes to their sizes, arrangement, type of housing stock, and use. Areas that do not meet user needs (irrespective of their functions) and preferences are neglected, get derelict and depopulated, idle, they stagnate and then they are gradually eliminated. This condition can be described by the term ' degradation' understood in this case as a spontaneous, unplanned and uncontrolled process of considerable loss of value (wear and tear) of physical substance (buildings and equipment) within urban space combined with the destruction or distortion of stable social bonds amongst its users. Although degradation can be observed in every city, it takes different courses depending on the specificity of local circumstances. It tackles areas performing different functions, which 
go to rack and ruin gradually or rapidly and usually need intervention, a remedy action aimed to introduce new organisation and arrangement of space. Contemporary cities experience different types of degradation of their spatial, functional, social, and cultural structures. Material aspect of urban degradation, i.e., the destruction of physical substance (buildings and elements of infrastructure) directly reduces the value of real estate in the area causing its stagnation followed by the failure of local businesses and other activities. Social degradation signalled by indicators such as poverty, unemployment, social exclusion, pathologies (increased crime rates) are also unfavourable phenomena as they generate conflicts among residents and other users and directly intensify material degradation. As a result, we witness a decreasing social value of an area understood as the adjustment of space organisation, its institutional capacity and aesthetics to the needs of inhabitants and users. Depending on the size of a city measured with its population, the scale of degradation evolves, together with the leading qualities and effects, in particular in the context of the loss of social value. The multiplicity of forms of degradation, which can be observed in a city with respect to physical substance and social structures produces long-term adverse consequences in space organisation and in how it is used by different groups of users. Degradation of a city belongs to processes and occurrences leading to demolition understood as destruction of its structures that produces morphological, functional, social, and cultural changes. By adopting the above interpretation of demolition for the purpose of urban studies we expand the approach to the analysis of processes and occurrences, which adversely affect urban spatial, functional, and social structures. Learning about the origins, course, and effects of demolition and identifying its types and circumstances is not only a fascinating research problem but also an opportunity to propose effective modernising solutions, which help cities better meet the needs and requirements of not only present but future users.

Investigation into the history of development of cities clearly shows that demolition makes an integral component of urban growth. Depending on the reason behind the process, we can distinguish between demolition caused by the forces of nature or by anthropogenic factors. Both types relate to the material as well as social and cultural dimension of a city. Natural and anthropogenic demolition factors may lead a city to annihilation, they may destroy it or gradually degrade its physical structures, cultural heritage, inflict an economic disaster, and force residents to leave the city which, if abandoned, goes into rack and ruin. We can mention some well-known extreme cases of immediate demolition/ruining of normally functioning cities triggered by an external factor (volcano eruption) and including total extermination of the population (Herculaneum and Pompeii). Usually urban demolition caused by the forces of nature is a shortterm rapid occurrence, difficult to predict whose intensity and scope depend, inter alia, on the strength and length of impact of the destroying factor, local circumstances, in particular the type of housing and residents' preparedness. Examples of urban demolition caused by anthropogenic factors may refer to different time intervals but ruining in this case is either deliberate or unintended. As a result, demolition may cover individual facilities, districts or all of urban physical space and destroy the social space. Knocking down buildings, elimination of jobs or leisure areas undoubtedly reduce the comfort of living to local residents and significantly restrict the number of users arriving to these urban areas. A number of actions, especially those undertaken in the time of conflict, are openly intended to destroy the social space because they include extermination or expulsion of residents. In the time of peace, demolition is encouraged by negligence and mismanagement, global economic crises, cultural transformations and other specific factors that affect life in cities. Hence, we may consider 
demolition against the background of a variety of consequences produced by the process, such as material destruction, unfavourable economic changes, destabilisation of population, deterioration of living conditions and the quality of life of residents, and decreased social value of the city. Demolition of buildings, as well as demolition of the social tissue, has a direct impact upon the economy and other immeasurable functions performed by the city in the field of culture or landscape. Thus, the distortion of space organisation or total eradication of components of urban landscape which cannot be restored should be highlighted as effects of human-inflicted demolition. Moreover, demolition, in particular at tangible level, sometimes reveals cultural tiers, which provide valuable content that improves our knowledge about the history of a settlement in question or discovers ruins that are traces left by past events. Demolition of culture, its values and meanings encapsulated in urban landscape quite frequently lead to strong, often dramatic conflicts among diverse user groups in cities who differ with respect to the view of world and interpretation of past events whose traces can be found in the landscape.

In principle, all the above-mentioned types of demolition call for actions geared towards stopping the process, launching remedy measures, re-building and modernising space organisation in a way specific to a particular location. All of these necessary steps involve making choices and taking decisions, which may disintegrate or integrate communities, exert an impact not just upon a given city but also at regional or supra-regional levels. It means demolition is a process, which always poses a threat to stable functioning of a city, in which it is taking place. On the other hand, one needs to bear in mind that a city could not develop without damage caused deliberately to obsolete or dysfunctional material structures, which are either worn out, or fail to meet new needs.

Outcomes of demolition are very diverse and they are not only negative as the term would suggest but can also be positive and constructive. In certain contexts and under certain circumstances destruction in a city may be creative, for instance, when material infrastructure that no longer meets user's needs is eliminated to modify space organisation and improve its arrangement. By linking directly destruction with renovation we can transform the city in one of the most efficient ways, however, we need to proceed in a manner that is coordinated and well thought over. If demolition is to become an approved element of creative transformations, it must follow specific criteria. First and foremost, we need to unambiguously find out why it is taking place, identify its territorial scope, types of action and assess consequences that have already become visible at material and social levels. Only then can we use it consciously in planning and putting in place remedies targeting dysfunctional areas of the city.

Invalid, dysfunctional areas in cities can be transformed in many ways to improve space organisation often with the involvement of demolition. Material objects and infrastructure (if they are worn out, do not match the place or malfunction) can be demolished and replaced with new ones erected to better meet new needs. Another remedy option is to preserve the existing structures (despite their dysfunctionality), however, they should be thoroughly modernised and supplemented with new objects. In the first approach, demolition is understood as the condition of material substance but also as a tool that helps transform a particular area (through demolition of existing structures), radically clear it from previous functions to enable bringing in new organisation of space. It is a creative destruction. According to the second approach, demolition refers to the condition of the substance meaning remedy measures preserve the existing structures and the scope of transformations is smaller and less radical. In a particular location, the choice between the two above-mentioned types of transformation of dysfunctional and demolished material tissue into a better organised space always depends on individual circumstances 
(e.g., present and planned function of a territory, its size and importance, historical value, central or peripheral location, technical condition of facilities, etc.).

It is much more complicated to transform dysfunctional social tissue, filled with conflicts (over racial, ethnic or religious issues), suffering from adverse social occurrences (unemployment, exclusion, and poverty), and pathologies (alcoholism, drug addiction, criminality). Demolition at the social level tackles people and relationships among them. Remedy process geared towards eliminating negative social occurrences is not easy as its practical implementation calls for collaboration and approval of those whom it directly targets. Besides, social changes are usually spread over time, which clearly impedes quick wins in pursuing these transformations. Due to the complexity of reasons that trigger it, social demolition is an extremely difficult challenge to designing and carrying out remedy and recovery programmes. The same can be said about cultural dimension of urban demolition. Usually it is linked directly with the destruction of material substance and coupled with existing social problems. Being a hugely complex issue, demolition not always allows us to develop a fully planned and implementable remedy process. As we have already demonstrated, although demolition may in some instances be approached as a specific opportunity for radical improvement of the current condition and elimination of problems in space organisation in the city, where it takes place, its multiple meanings and complexity necessitate multidimensional (spatial, social, cultural) detailed diagnoses and analyses to be conducted on a case by case basis.

Speaking of remedy effort undertaken in invalid, dysfunctional, degraded areas, it is worth looking at regeneration as a particularly interesting way of transforming spatial (material), functional, social, and cultural structures in cities that has been carried out in different countries for several decades already. It consists in implementing planned changes in the organisation of dysfunctional, degraded, invalid spaces in urban areas to successfully revive them as a result of a sequence of integrated spatial, economic, cultural or social actions. Regeneration always exerts multidimensional impact upon the location, in which it takes place. Depending on the local context, transformation can be driven by intra-city factors or external, often global circumstances (e.g., changes in global transportation system or relocation of some industrial activities to other regions). Regeneration is omnipresent in cities across the world; it takes a number of forms in areas performing different functions. Undoubtedly, nowadays it is one of the most frequent and the most significant ways of urban modernisation. There is an abundant research literature that addresses theoretical and empirical ways of identification of the reasons, courses, types, and effects of urban regeneration but it is dispersed across many disciplines. Studies in this area are conducted predominantly by urban geographers, urban planners, spatial planners, sociologists but also, although in a more narrow sense, by economists, social anthropologists, researchers in cultural studies, psychologists, and lawyers. Interdisciplinary nature of these research achievements devoted to regeneration results, on the one hand, from the complexity and contextual nature of the process and, on the other hand, from the complexity of a city as an organism subject to regeneration. Urban regeneration is discussed by researchers from different disciplines meaning it is examined through the lens of a variety of methodological approaches specific for these disciplines. Each of them focus mostly on a fraction of the process or selected circumstances which have shaped its origin, course, and effects.

According to urban studies, transformation is always discussed in the context of a certain area (part of a city) of unspecified size; its scale may easily range from a district (a set of blocks) to a block (including plots, streets and buildings). The substance of such transformation always consists in reviving an area in question to meet user needs (present and future) in the best possible manner. Yet, causes, course, and effects of the process 
are conditioned with the topographic setting and depend on where transformation actually takes place (all over the city or in one of its parts). Multidimensionality is another critical feature of the process. On many occasions authors stress that this is a crucial quality, which differentiates the above mentioned process from other forms of transformations carried out in urban space, which are restricted to technical interventions, such as, e.g., a major repair, renewal or revitalisation (Ziobrowski et al. 2000; Kaczmarek 2001, 2015; Jones \& Evans 2008, 2013; McCarthy 2007, Leary \& McCarthy 2013). Multidimensionality of regeneration is thus decisive for its comprehensiveness understood as a coherence of different activities undertaken to revive a distressed area or an area which has ultimately lost its previous functions. In other words, the multidimensionality of regeneration consists in adopting remedy efforts not only with respect to the material substance or economic sphere but it should stimulate positive and sustainable changes within the local community.

The following four dimensions are the most often mentioned with respect to regeneration: spatial (spatial layout and the housing stock), economic (functions of a city), social, and cultural (Kaczmarek 2001). Some researchers also highlight the environmental dimension (Markowski \& Stawasz 2007), which links directly with the sustainable development idea and its importance in planning and management which has been growing since the late 20th century. Since all cities are unique, regeneration is bound with the location, in which it takes place and it is always unique, which is why regeneration programmes and ways of implementing the proposed transformations must always be developed on a case-by-case basis.

Both the above-mentioned processes: demolition and regeneration make an integral part of the history of development of cities in the world and, from that perspective, examining them is an interesting exercise. Especially fascinating are the relationships between regeneration and demolition, that is, ruining of an area as a result of natural disasters or human decisions and actions or a combination of both. The link between demolition and regeneration is obvious on the face of it: since an area is degraded it should be renewed and revived, it needs regeneration interpreted as multidimensional transformation. Different types of demolition that have been presented above generate effects, which depend on the local context of a particular location, on its physical, geographic, geopolitical, economic, social, and cultural circumstances but at the same time they trigger diverse remedy scenarios. As noted by Lévy and Lussault (2013), from urban planning point of view demolition as a process adds on dynamics into modernisation of a city assuming it is accompanied by introducing new forms of urban space management. Contemporary approach to demolition used as a tool in regeneration is much more liberal and much more often deployed although not at such a big scale as it was the case until the 1960s in North America and in (mainly) Western Europe. By reviewing actions undertaken under the umbrella of regeneration in dynamically developing cities of South America and Asia, especially China, we may conclude that the scale of demolition used as an instrument aimed to revive urban areas there is huge. Also in Europe, in countries like the United Kingdom, France, and Germany demolition makes a vital component of urban policy. The case of Germany is interesting in this context as following reunification people would massively migrate from lands situated in the east to the western parts of the country. As a result, in territories of the former German Democratic Republic (GDR) deserted housing districts emerged (mainly built of prefabricated construction materials). Demolition deployed there to eliminate some of the obsolete housing stock became a relevant part of management rationalisation, re-urbanisation, and regeneration of cities even though concerns were raised over how the policy was implemented - in accordance with the idea of 'shrinking' or 'perforated' city (Florentin 2010). 
But is it really the only one relationship between the two processes? In the light of creative destruction we may assume that under some specific circumstances demolition makes an integral part of regeneration. Transformations introduced while modernising and reviving an area may call for total eradication of the previous arrangement and equipment which for different reasons (e.g., technical shape, contamination, etc.) may not be modernised and effectively adapted to new functions. In such occasions, demolition, i.e., destruction of obsolete structures, becomes a rational instrument of the remedy process. The above described way of using demolition can be compared to a surgery as a result of which infected tissue is removed to help the organism, in our case a city, to recover.

Modification of organisation of the space of exchange which takes place in the course of demolition and regeneration is an issue which can be discussed against already classical theories in urban geography: economic base and functional structure of a city, morphological evolution or social and spatial structure of a city as well as in the context of more recent and often quoted theoretical concepts: shrinking city, compact city, sustainable city, liveable city and resilient city.

The to-date scientific achievements in contemporary urban geography help us distinguish some lines of thought and research approaches which identify contexts of mutual relations of the two processes. We can mention here works in which demolition treated as a city-forming factor is analysed in morphological aspect in the context of urban plot evolution theory (Conzen 1960, 1962; Koter 1979, 1990; Slater 1981, 1990; Larkham 1988, 1991; Whitehand 1988, 1989) or with reference to urban space modernisation processes (Harvey 1989; Jacobs 1993; Power 1993; Mumford \& Power 2002; Weber et al. 2006; Johansson 2011), and especially the elimination of shanty houses as a tool of social control and urban policy (Weicher 1972; Furedi 1973; Chege 1981; Werlin 1981; Bauman 1983; Jackson 1985; Macharia 1992; Biles
2000; Otiso 2002, 2005; Self 2003; Jones 2004; Davis 2006; Highsmith 2009; Hunt 2009). Slightly different contexts of demolition and its relationships with regeneration can be found in works addressing issues such as regeneration mega-projects, gentrification (Spain 1989; Smith \& DeFilippis 1999; Smith 1996; Mele 2000; Kennedy \& London 2001; Betancur 2002), uncontrolled urban heritage shrinkage and the need to preserve historically valuable structures (Abbas 2002; Xu 2004; Weber et al. 2006; Ren 2008; Siravo 2009; Shih 2010; Power 2010; Janoschka et al. 2014; McGuirk 2014; Sigler 2014; Egecioglu et al. 2016) or demolition as part of urban shrinkage (Bontje 2004; Reckien \& Martinez-Fernandez 2011; Mallach 2012; Wiechmann \& Palgast 2012; Wiechmann \& Bontje 2013; Krzysztofik et al. 2015; Radzimski 2016). Links between regeneration and demolition are also reflected in studies on the value of land in cities, real estate speculation, impact of different groups of economic and political interests, and urban regime theory (Fine \& Lindberg 2002; Weber et al. 2006; Wu et al. 2007; Ren 2008, 2011, 2013, 2014; Johansson 2011; Visser 2010). Researchers are also interested in seeing and presenting demolition as a sector of economy (urban mining and creative recycling), a source of recycled construction materials often used in investment projects carried out within regeneration programmes (Rosenthal \& Helsley 1994; Byles 2005; Deilmann et al. 2009; Diver \& Shaurette 2010; lacoboaea et al. 2010; Hiete et al. 2011). Thus, we may conclude that the pool of scientific achievements emerging globally and related to regeneration and demolition treated as separate processes as well as links between the two, although vast and versatile, has been poorly systemised and organised at methodological and terminological levels.

Diversity of aspects and forms of demolition in the context of transforming urban space organisation and the functioning of a city as a social structure make it a fascinating research problem which needs to be further examined. The need for more in-depth 
studies is also evidenced by vivid discussions of researchers that take place at scientific conferences organised at the global level. Separate sessions of presentations devoted to regeneration and its relationships with demolition were recently organised during such prominent scientific conferences as the 7th Nordic Geographers Meeting in Stockholm in 2017 and the Regional Conference of the International Geographical Union in Quebec City in 2018. The preparation of this thematic issue of GEOGRAPHIA POLONICA concerning the diversity of demolition process and its relation to the urban regeneration refers to the trend. Authors of this special issue raised several research questions and problems that illustrate various contexts and approaches to the processes of demolition and urban regeneration as well as their mutual relations mentioned above. These are as follows:

- the structure of relationships among ruins, economic change, demographic change, social geography and the characteristics of buildings examined with the use of Multiple Linear Regression Analysis EBH is the subject of Eduardo Brito Henriques and David Cruz contribution (Henriques \& Cruz 2019);

- the demolition of housing estates, analysed in the light of technical and normative evolutions (security, recycling), receives particular attention in the paper by Laëtitia Mongeard and Vincent Veschambre (Mongeard \& Veschambre 2019) as well as their political and ideological meanings is presented by Lydia Coudroy de Lille and Guénola Inizan (Coudroy de Lille \& Inizan 2019);

- urban regenerating projects as the attempt to improve the ruined/demolished urban tissue and to mitigate inequality within the city analysed by Nico Kotze and Leani de Vries (Kotze \& de Vries 2019);

- processes of ruination, demolition and urban renewal and their influence on the cultural attitudes towards ruins, demolition, memory, and memorialisation, characterised by Luke Bennett (Bennett 2019);
- urban regeneration projects implying changes in the meanings encoded in space, which are not always welcome and may lead to public discussions and conflicts and result in the demolition of semiosphere explored by Armina Kapusta (Kapusta 2019);

- the importance of planned demolition in urban regeneration projects undertaken to re-integrate the city developed by Jarosław Kazimierczak and Karolina Wrona (Kazimierczak \& Wrona 2019);

- planned demolition as a tool for large scale spatial and functional transformation of inner city in regeneration megaprojects described by Piotr Kosmowski (Kosmowski 2019).

The complexity of research problems involved in the identification and examination into the relationships between demolishing a city and its regeneration provides food for thought to consider the following issues which have been formulated as research questions that delineate further stages of interdisciplinary scientific effort:

- What are the origin, course and effects of ruining and demolishing cities under various physical, geographical, economic, geopolitical, ideological and cultural circumstances?

- Which factors contribute to the ruining/ demolishing of cities (in the past and at present)?

- How does ruining/demolishing progress in cities? What consequences does it bring?

- What are the relations between ruining, demolishing and urban regeneration in contemporary cities in various cultural and social aspects?

- Is ruining/demolishing linked with sustainable development of cities and, if yes, how and to what extent?

- Can demolition be considered a part of the process which supports the elimination of inequalities in urban space?

- What are axiological contexts of demolition and regeneration in cities about?

- To what extent we can speak of similarities and differences between the origins, 
courses, and effects of demolition and regeneration in different geographic regions of the world?

- How well can we identify symptoms of demolition in the social tissue resulting from an implemented regeneration project (the so-called regeneration trauma)?

- How do different forms of individual and social empowerment promoted in urban regeneration programs prevent/ or may potentially prevent the emergence of social inequality in space?

The above listed issues necessitate detailed interdisciplinary field studies which would allow learning about the specificity of both processes in situ and greatly increase the validity of formulated conclusions and presented interpretations. Both processes: demolition and regeneration are multidimensional, they carry spatial, economic, social, and cultural references, they are clearly contextual, i.e., strongly bound with the place, in which they are implemented. Regeneration and demolition/ruining are contextual

\section{References}

AbBAS A., 2002. Play it again Shanghai: Urban preservation in the global era [in:] M. Gandelsonas (ed.), Shanghai reflections: Architecture, urbanism and the search for an alternative modernity, Princeton Architectural Press, Princeton, New Jersey, pp. 36-55.

BAUMAN J.F., 1983. Visions of a post-war city [in:] D.A. Krueckeberg (ed.), Introduction to planning history in the United States, New Brunswick: Rutgers University Center for Urban Policy Research, pp. 170-89.

Bennett L., 2019. Grubbing out the Führerbunker: Ruination, demolition and Berlin's difficult subterranean heritage. Geographia Polonica, vol. 92, no. 1, pp. 71-82.

BETANCUR J.J., 2002. The politics of gentrification: The case of West Town in Chicago. Urban Affairs Review, vol. 37, no. 6, pp. 780-814.

BILES R., 2000. Public housing and the postwar urban renaissance, 1949-1973 [in:] J.F. Bauman, because cities are unique. There is nothing like two identical cities (at material, social, and cultural level) so there are no identical processes of demolition and regeneration. Contextuality is strictly conditioned by physical, geographic, social and cultural, political, economic, as well as legal and administrative factors which determine the life of each city. By considering their importance for the analysis and interpretation of the coexistence of demolition and regeneration in cities we open up the opportunity to formulate modern theoretical and planning theories about the shaping of cities of the future, which - being filled with properly organised and equipped spaces responding to user needs - will ensure sustainable comfort of living to their residents.

\section{Acknowledgements:}

This contribution is financed by National Science Centre of Poland based on decision no. DEC-2014/15/B/HS4/01940.

R. Biles, K. Szylvian (eds.), From tenements to the Taylor homes: In search of an urban housing policy in twentieth century America, University Park: Pennsylvania State University Press, pp. 143-162.

BONTJE M., 2004. Facing the challenge of shrinking cities in East Germany: The case of Leipzig, GeoJournal, vol. 61, no. 1, pp. 13-21.

Brito-Henriques E., Cruz D., 2019. Seeking the causes of urban ruination: An empirical research in four Portuguese cities. Geographia Polonica, vol. 92, no. 1, pp. 17-36.

BYLES J., 2005. Rubble: Unearthing the history of demolition. New York: Three Rivers Press.

CHEge M., 1981. The tale of two slums: Electoral politics in Mathare and Dagoretti. Review of African Political Economy, vol. 8, no. 20, pp. 74-88.

Conzen M.R.G., 1960. Alnwick, Northumberland: A study in town-planning analysis. Transactions and Papers, Publication no. 27, London: Institute of British Geographers. 
Conzen M.R.G., 1962. The plan analysis of an English city centre [in:] K. Norborg (ed.), Proceedings of the IGU Symposium in Urban Geography: Lund 1960, Lund Studies in Geography B, vol. 24, pp. 384-414.

Davis M., 2006. Planet of slums. London: Verso.

Deilmann C., Effenberger K.H., Banse J., 2009. Housing stock shrinkage: Vacancy and demolition trends in Germany. Building Research \& Information, vol. 37, no. 5-6, pp. 660-668.

Diver R.J., Shaurette M., 2010. Demolition: Practices, technology, and management. West Lafayette: Purdue University Press.

EgercioĞlu Y., Yakici N., ERTAN T., 2016. Urban decline and revitalization project in Izmir-Tire historical city center. Procedia - Social and Behavioral Sciences, vol. 216, pp. 330-337.

FINE A.S., LINDBERG J., 2002. Protecting America's historic neighborhoods: Taming the teardown trend. Washington, D.C.: National Trust for Historic Preservation.

FLORENTIN D., 2010. The 'perforated city': Leipzig's model of urban shrinkage management. Berkeley Planning Journal, vol. 23, no. 1, pp. 83-101.

FUREDI F., 1973. The African crowd in Nairobi: Popular movements and elite politics. Journal of African History, vol. 14, no. 2, pp. 275-290.

HaRVEY D., 1989. From managerialism to entrepreneurialism: The transformation in urban governance in late capitalism. Geografiska Annaler: Series B, Human Geography, vol. 71, no. 1, pp. 3-17.

Hiete M., Stengel J., Ludwig J., Schultmann F., 2011. Matching construction and demolition waste supply to recycling demand: A regional management chain model. Building Research \& Information", vol. 39, no. 4, pp. 333-351.

Highsmith A.R., 2009. Demolition means progress: Urban renewal, local politics, and state-sanctioned ghetto formation in Flint, Michigan. Journal of Urban History, vol. 35, no. 3, pp. 348-368.

Hunt D.B., 2009. Blueprint for disaster: The unraveling of Chicago public housing. Chicago: University of Chicago Press.

Iacoboaea C., Luca O., Aldea M., Sercaianu M., 2010. Main issues related to the construction and demolition waste management in Romania. WIT Transactions on Ecology and the Environment, vol. 129, pp. 533-544.
InizAN G., Coudroy de Lille L., 2019. The last of the Soviets' Home: Urban demolition in Moscow. Geographia Polonica, vol. 92, no. 1, pp. 37-56.

JACOBS J., 1993. The death and life of great American cities. New York: Modern Library.

JanoschKa M., Sequera J., Salinas L., 2014. Gentrification in Spain and Latin America - A critical dialogue. International Journal of Urban and Regional Research, vol. 38, no. 4, pp. 1234-1265.

JohansSON B.O.H., 2011. The post-war destruction of Swedish cities. Building Research \& Information, vol. 39, no. 4, pp. 412-429.

JONES E.M., 2004. The slaughter of cities: Urban renewal as ethnic cleansing. South Bend: St. Augustine Press.

Jones P., Evans J., 2008. Urban regeneration in the UK. London: Sage Publications Ltd.

KaczmareK S., 2001. Rewitalizacja terenów poprzemysłowych: Nowy wymiar $w$ rozwoju miast. Łódź: Wydział Uniwersytetu Łódzkiego [Thesis dissertation].

KACZMAREK S., 2015. Skuteczność procesu rewitalizacji. Uwarunkowania, mierniki, perspektywy. Studia Miejskie, vol. 17, pp. 27-35.

Kaczmarek S., 2017. Demolowanie jako radykalne narzędzie $w$ procesie rewitalizacji. Studia Miejskie, vol. 28, pp. 9-20.

Kaczmarek S., Kazimierczak J., Coudroy De Lille L., Monegard L., 2018. Demolowanie terenów miejskich: Synergia w badaniach geograficznych w Polsce i we Francji [in:] M. Więckowski, M. Jędrusik, L. Coudroy de Lille, A. Le Blanc (eds.), Geografia. Wspólne idee, wspólne wizje. Sto lat współpracy polsko-francuskiej, Warszawa: Wydział Geografii i Studiów Regionalnych UW, pp. 97-114.

KAPUSTA A., 2019. The Vardar River as a border of semiosphere - Paradox of Skopje regeneration. Geographia Polonica, vol. 92, no. 1, pp. 83-102.

KaZIMIERCZAK J., Wrona K., 2019. Regeneration and demolition vis-á-vis disintegration of urban space: The case of el Cabanyal-Canyamelar in Valencia. Geographia Polonica, vol. 92, no. 1, pp. 121-139.

Kennedy M., London P., 2001. Dealing with neighborhood change: A primer on gentrification 
and policy choices. Washington, D.C.: Brookings Institution.

KosmowsKI P., 2019. Demolition in regeneration megaprojects: The case of Wien Hauptbahnhof. Geographia Polonica, vol. 92, no. 1, pp. 141-156.

Koter M., 1994. Od fizjonomii do morfogenezy i morfologii porównawczej. Podstawowe zagadnienia teoretyczne morfologii miast. [in:] M. Koter, J. Tkocz (eds.), Zagadnienia geografii historycznej osadnictwa w Polsce. Materiały konferencyjne, UMK, UŁ, Toruń-Łódź: Uniwersytet Mikołaja Kopernika, Uniwersytet Łódzki, pp. 23-32.

Kotze N., de VRIES L., 2019. Resuscitating the African giant: Urban regeneration and inner city redevelopment initiatives along the 'Corridors of Freedom' in downtown Johannesburg. Geographia Polonica, vol. 92, no. 1, pp. 57-70.

Krzysztofik R., DYMitrow M., SzMytKie R., Kantor-Pietraga I., Petka-Gościniak J., Spórna T., 2015. Environmental hazards and urban abandonment: Case studies and typological issues, Geografiska Annaler: Series B, Human Geography, vol. 97, no. 4, pp. 291-308.

LARKHAM P.J., 1988. Aesthetic control, architectural styles and townscape change. Occasional Publication, vol. 25, Birmingham: University of Birmingham, Department of Geography.

LARKHAM P.J., 1991. Planning and the historical townscape. Habitat International, vol. 15, no. 1-2, pp. 219-237.

Leary M.E., McCarthy J. (eds.), 2013. The Routledge companion to urban regeneration. London-New York: Routledge.

Lévy J., Lussault M. (eds.), 2013. Dictionnaire de la géographie. Paris : Belin.

MACHARIA K., 1992. Slum clearance and the informal economy in Nairobi. The Journal of Modern African Studies, vol. 30, no. 2, pp. 221-236.

Mallach A. (ed.), 2012. Rebuilding America's legacy cities: New directions for the industrial heartland. New York: The American Assembly and Columbia University.

Markowski T., Stawasz D. (eds.), 2007. Rewitalizacja a rozwój funkcji metropolitalnych miasta Łodzi. Łódź: Wydawnictwo Uniwersytetu Łódzkiego.

Martinez-Fernandez C., Audirac I., Fol S., Cunningham-SABOt E., 2012. Shrinking cities:
Urban challenges of globalization. International Journal of Urban and Regional Research, vol. 36, no. 2, pp. 213-225.

McCarthy J., 2007. Partnership, collaborative planning and urban regeneration. Farnham: Ashgate Publishing.

McGuirk J., 2014. Radical cities: Across latin America in search of a new architecture. New York: Verso.

MeLE C., 2000. Selling the lower east side: Culture, real estate, and resistance in New York City. Minneapolis: University of Minnesota Press.

Mongeard L., Veschambre V., 2019. Renovation and monumentality in social housing: Analysis of demolitions of towers and slabs from the case study of the Lyon urban area in France. Geographia Polonica, vol. 92, no. 1, pp. 103-119.

Mumford K., Power A., 2002. Boom or abandonment: Resolving housing conflicts in cities. Coventry: Chartered Institute of Housing.

Otiso K., 2002. Forced evictions in Kenyan cities. Singapore Journal of Tropical Geography, vol. 23, no. 3, pp. 252-267.

Otiso K., 2005. Colonial urbanization and urban management in Kenya [in:] S. Salm, T. Falola (eds.), African urban spaces, Rochester: University of Rochester Press, pp. 73-97.

POWER A., 1993. Hovels to high rise: State housing in Europe since 1850. London: Routledge.

RADZIMSKI A., 2016. Changing policy responses to shrinkage: The case of dealing with housing vacancies in Eastern Germany. Cities, vol. 50, pp. 197-205.

Reckien D., Martinez-Fernandez C., 2011. Why do cities shrink? European Planning Studies, vol. 19, no. 8, pp. 1375-1397.

REN X., 2008. Forward to the past: Historical preservation in globalizing Shanghai. City and Community, vol. 7, no. 1, pp. 23-43.

REN X., 2011. Building globalization: Transnational architecture production in urban China. Chicago: University of Chicago Press.

Ren X., 2013. Urban China. Cambridge: Policy.

REN X., 2014. The political economy of urban ruins: Redeveloping Shanghai. International Journal of Urban and Regional Research, vol. 38, no. 3, pp. 1081-1091. 
Rosenthal S., Helsley R., 1994. Redevelopment and the urban land price gradient. Journal of Urban Economics, vol. 35, no. 2, pp. 182-200.

Self R.O., 2003. American Babylon: Race and the struggle for postwar Oakland. Princeton, New Jersey: Princeton University Press.

SHIH M., 2010. The evolving law of disputed relocation: Constructing inner-city renewal practices in Shanghai, 1999-2005. International Journal of Urban and Regional Research, vol. 34, no. 2, pp. 350-364.

SigleR T.J., 2014. Monaco with bananas, a tropical Manhattan, or a Singapore for Central America? Explaining rapid urban growth in Panama City. Singapore Journal of Tropical Geography, vol. 35, no. 2, pp. 261-278.

Siravo F., 2009. Historic cities and their survival in a globalized world [in:] Proceedings: X World Congress of the Organization of World Heritage Cities: Quito 2009, 8-11 September, pp. 14-35.

SLATER T.R., 1981. The analysis of burgage patterns in medieval towns. Area, vol. 13, no. 3, pp. 211-216.

Slater T.R., 1990. English medieval new towns composite plans: Evidence from the Midland [in:] T.R. Slater (ed.), The built form of Western cities, Leicester-London: Leicester University Press, pp. 60-82.

SмiтH N., 1996. The new urban frontier: Gentrification and the revanchist city. New York: Routledge.

SmitH N., DeFilippis J., 1999. The reassertion of economics: 1990s gentrification on the lower east side. International Journal of Urban and Regional Research, vol. 23, no. 4, pp. 638-653.

SPAIN D., 1989. Why higher income households move to central cities?. Journal of Urban Affairs, vol. 11, no. 3, pp. 283-299.

VISSER R., 2010. Cities surround the countryside: Urban aesthetics in postsocialist China. Durham, NC.: Duke University Press.

Weber R., Doussard M., Dev Bhatta S., McGrath D., 2006. Tearing the city down:
Understanding demolition activity in gentrifying neighborhoods. Journal of Urban Affairs, vol. 28, no. 1, pp. 19-41.

Weicher J.C., 1972. Urban renewal: National program for local problems. Washington, D.C.: American Enterprise Institute for Public Policy Research.

WERLIN H.H., 1981. The hawkers of Nairobi: The politics of the informal sector [in:] R.A. Obudho (ed.), Urbanization and development planning in Kenya, Nairobi: Kenya Literature Bureau, pp. 194-214.

WhiteHAND J.W.R., 1988. Urban fringe belts: Development of an idea. Planning Perspectives, vol. 3, no. 1, pp. 47-58.

Whitehand J.R.W., 1989. Residential development under restraint: A case study in London's rural-urban fringe. University of Birmingham Department of Geography Occasional Publication, no. 28, Birmingham: School of Geography, University of Birmingham.

Wiechmann T., Bontue M., 2013. Responding to tough times: Policy and planning strategies in shrinking cities. European Planning Studies, vol. 23, no. 1, pp. 1-11.

Wiechmann T., Pallagst K., 2012. Urban shrinkage in Germany and the USA: A comparison of transformation patterns and local strategies. International Journal of Urban and Regional Research, vol. 36, no. 2, pp. 261-280.

Wu F., XU J., YeH A.G.O., 2007. Urban development in post-reform China: State, market and space. New York: Routledge.

Xu M., 2004. Shanghai zhongxincheng jiuzhuqu fazhan fangshi xinlun [Redevelopment of old neighborhoods in inner-city Shanghai]. Shanghai: Xuelin Press.

ZIOBROWSKI Z., PtASZYCKA-JaCKOWSKA D., RęBOWSKAA., GeISSLER A. (eds.), 2000. Odnowa miast: Rewitalizacja, rehabilitacja, restrukturyzacja. Kraków: Instytut Gospodarki Przestrzennej i Komunalnej.
(C) Sylwia Kaczmarek

(C) Geographia Polonica

(C) Institute of Geography and Spatial Organization

Polish Academy of Sciences • Warsaw • 2019
Article first received • October 2018 Article accepted • January 2019 